\title{
ALS mutations in TLS/FUS disrupt target gene expression
}

\author{
Tristan H. Coady and James L. Manley \\ Department of Biological Sciences, Columbia University, New York, New York 10027, USA
}

\begin{abstract}
Amyotrophic lateral sclerosis (ALS) is caused by mutations in a number of genes, including the gene encoding the RNA/DNA-binding protein translocated in liposarcoma or fused in sarcoma (TLS/FUS or FUS). Previously, we identified a number of FUS target genes, among them MECP2. To investigate how ALS mutations in FUS might impact target gene expression, we examined the effects of several FUS derivatives harboring ALS mutations, such as R521C (FUS ${ }^{\mathrm{C}}$ ), on MECP2 expression in transfected human U87 cells. Strikingly, FUS ${ }^{\mathrm{C}}$ and other mutants not only altered MECP2 alternative splicing but also markedly increased mRNA abundance, which we show resulted from sharply elevated stability. Paradoxically, however, MeCP2 protein levels were significantly reduced in cells expressing ALS mutant derivatives. Providing a parsimonious explanation for these results, biochemical fractionation and in vivo localization studies revealed that $M E C P 2$ mRNA colocalized with cytoplasmic $\mathrm{FUS}^{\mathrm{C}}$ in insoluble aggregates, which are characteristic of ALS mutant proteins. Together, our results establish that ALS mutations in FUS can strongly impact target gene expression, reflecting a dominant effect of FUS-containing aggregates.
\end{abstract}

[Keywords: amyotrophic lateral scelerosis; gene expression; RNA processing; TLS/FUS]

Supplemental material is available for this article.

Received June 11, 2015; revised version accepted July 22, 2015.

Recent years have seen a striking increase in the number of diseases linked to perturbation of mRNA processing. Notable examples include the misregulation of pre-mRNA splicing that occurs in various cancers and neurodegenerative diseases (Baumer et al. 2010; David and Manley 2010; Zhang and Manley 2013). Examples of pathological RNA processing can be found in the neurodegenerative disease amyotrophic lateral sclerosis (ALS) (van Blitterswijk and Landers 2010; Polymenidou et al. 2012). A number of disparate genes have been identified as targets of ALS mutations (Renton et al. 2014), but how their dysfunction leads to disease onset is unknown. While some early studies described apparent defects in RNA processing in ALS patients (Lin et al. 1998), the first direct indication that splicing might be a relevant pathway arose from the discovery of mutations in the gene encoding TDP-43 (Sreedharan et al. 2008), a known RNA/DNA-binding protein previously implicated in splicing regulation (Buratti et al. 2001). Subsequently, mutations in translocated in liposarcoma or fused in sarcoma (TLS/FUS) (Crozat et al. 1993; Rabbitts et al. 1993) were discovered, first in familial ALS (Kwiatkowski et al. 2009; Vance et al. 2009) and subsequently in sporadic cases (Belzil et al. 2009; Conte et al. 2012; Sproviero et al. 2012). TLS/FUS (FUS) is an RNA/ DNA-binding hnRNP-like protein also implicated in splicing control (Crozat et al. 1993; Calvio et al. 1995; Wu and Green 1997), and its involvement in ALS strengthens the view that ALS may be an RNA processing disease.

Corresponding author: jlm2@columbia.edu

Article published online ahead of print. Article and publication date are online at http://www.genesdev.org/cgi/doi/10.1101/gad.267286.115.
FUS (also known as TLS) has a number of intriguing features that suggest that it plays significant roles in gene control. The protein is a member of the TET (TLS, EWS, and TAF15) family of proteins, which is implicated in both transcription and splicing (Tan and Manley 2009; Dormann and Haass 2013). TET proteins share similar domain organization and copurify or interact with transcription factors (TFIID and RNA polymerase II [RNAP II]) (Bertolotti et al. 1996; Law et al. 2006; Kwon et al. 2013) on the one hand and the spliceosome and SR protein-splicing factors (Yang et al. 1998; Rappsilber et al. 2002; Zhou et al. 2002; Meissner et al. 2003; Leichter et al. 2011) on the other, suggesting possible roles in coupling transcription and splicing. Considerable evidence implicates TET proteins in splicing control in vivo (Paronetto et al. 2011; Blechingberg et al. 2012), and FUS was shown to enhance RNAP II transcription while repressing RNAP III transcription in vitro (Tan and Manley 2010) and increase RNAP II phosphorylation, and thereby transcription elongation, in vivo (Schwartz et al. 2012). However, the relationship between FUS protein function and ALS pathology has yet to be elucidated.

Leading theories propose that ALS mutations cause pathological changes in gene expression/RNA processing (Polymenidou et al. 2012; Qiu et al. 2014). However, whether this reflects reduced function of the mutated

(C) 2015 Coady and Manley This article is distributed exclusively by Cold Spring Harbor Laboratory Press for the first six months after the full-issue publication date (see http://genesdev.cshlp.org/site/misc/ terms.xhtml). After six months, it is available under a Creative Commons License (Attribution-NonCommercial 4.0 International), as described at http://creativecommons.org/licenses/by-nc/4.0/. 
proteins, a toxic gain of function, or both is not known (Mackenzie and Neumann 2012). In FUS cases, FUS-containing cytoplasmic aggregates are observed in patient spinal cord motor neurons and ex vivo fibroblasts (Munoz et al. 2009; Neumann et al. 2009; Vance et al. 2013), similar to aggregates detected with TDP-43 mutant proteins (Bentmann et al. 2012). How such aggregates might contribute to ALS is unknown. An important question is whether ALS mutant FUS proteins can lead to altered splicing and/or expression of specific genes. We previously used a chromatin immunoprecipitation (ChIP) promoter microarray approach to identify putative FUS target genes and showed that several of them could indeed be regulated by FUS (Tan et al. 2012). One of these genes was MECP2, which is implicated in another neurological disease, Rett syndrome. Rett syndrome is an X-linked neuro-regressive disorder in which mutations in MECP2 result in loss of acquired cognitive abilities (Zoghbi 2005). MECP2 transcripts can be alternatively spliced to generate two isoforms, MECP2e1 (e1) and MECP2e2 (e2) (Kriaucionis and Bird 2004). The $e 2$ isoform is dispensable for development in mice (Itoh et al. 2012) but is important for neurite formation in neuronal cell models (Cusack et al. 2004; Jugloff et al. 2005). The e1 isoform is most highly expressed in neural tissues, and its contribution to pathogenesis was demonstrated by the finding that transgenic mice specifically lacking $e 1$ phenotypically recapitulate Rett syndrome (Dragich et al. 2007; Yasui et al. 2014). Neuroblastoma cell lines overexpressing either the $e 2$ or $e 1$ isoform individually displayed unique gene expression changes (Orlic-Milacic et al. 2014), demonstrating the importance of $M E C P 2$ alternative splicing.

Here we show that FUS derivatives containing ALS mutations result in drastic disruption of MECP2 expression in cultured U87 glioblastoma cells. We first identified a splicing switch from the full-length e2 isoform to the exon 2-excluded e1 isoform in U87 cells expressing FUS derivatives with ALS mutations. This was accompanied by an increase in e1 mRNA levels beyond that produced by the splicing change, which we show reflects increased mRNA stability. Surprisingly, however, MeCP2 protein levels were substantially reduced. Providing an explanation for these findings, we show, using biochemical and in situ staining assays, that MECP2 mRNA colocalizes with FUS mutant proteins in insoluble cytoplasmic aggregates. Together, our results provide evidence that ALS mutations in FUS can cause severe disruptions in target gene expression, strengthening the view that alterations in mRNA metabolism, mediated at least in part by toxic FUS-containing aggregates, contribute to ALS pathology.

\section{Results}

Expression of ALS FUS mutant proteins deregulates MECP2 mRNA splicing

We initially hypothesized that the mechanism by which FUS mutations lead to disease could be attributed at least in part to inappropriate neuronal gene expression due to alterations in FUS function. To test this idea, we first introduced several known ALS mutations-H517Q, R521C, R521H, and P525L-into Flag-tagged wild-type FUS, generating FUS ${ }^{\mathrm{Q}}, \mathrm{FUS}^{\mathrm{C}}, \mathrm{FUS}^{\mathrm{H}}$, and $\mathrm{FUS}^{\mathrm{L}}$ proteins, respectively. These derivatives were then expressed in the human glioblastoma cell line U87, and their subcellular localizations were verified by immunofluorescence with anti-Flag antibodies (Fig. 1). All four mutant proteins behaved consistent with previously observed localization patterns (Vance et al. 2013; Wang et al. 2013). In contrast to wild-type FUS, which was entirely nuclear, FUS ${ }^{\mathrm{C}}$ and FUS $^{\mathrm{H}}$ localized throughout the cell, while FUS ${ }^{\mathrm{L}}$ was predominantly cytoplasmic. These three proteins also all showed evidence of accumulation in cytoplasmic aggregates (Fig. 1, cf. wild-type FUS in the top row and mutant derivatives in the bottom three rows, aggregates are denoted by arrows, and the nuclear boundary is highlighted in blue via DAPI stain). FUS ${ }^{\mathrm{Q}}$ — which, unlike other characterized FUS ALS-associated mutations, is recessive (Bosco et al. 2010)—did not show cytoplasmic localization but did display altered nuclear accumulation such that the size and intensity of FUS-containing speckle-like nuclear structures were larger and more intense in FUS ${ }^{\mathrm{Q}}$-expressing cells compared with wild-type FUS (Fig. 1, cf. the second row and top row, respectively).

We next asked whether the ALS mutations impact the ability of FUS to modulate target gene expression. As

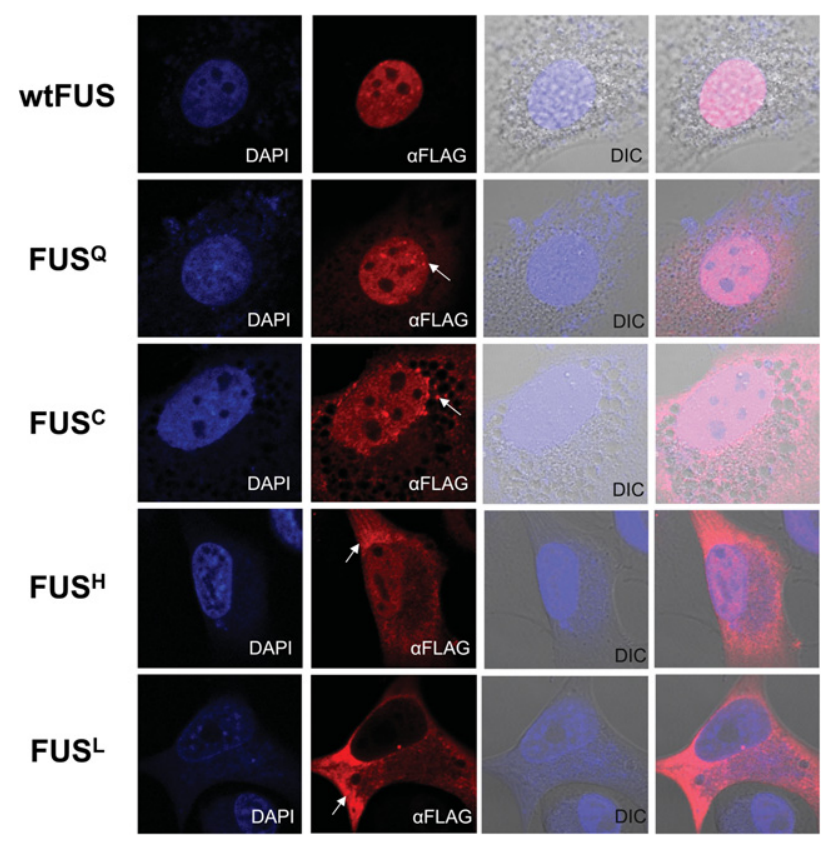

Figure 1. Recombinant FUS ALS mutant proteins mislocalize in U87 cells. Plasmids expressing different Flag-tagged FUS derivatives were transfected into U87 cells and fixed at $24 \mathrm{~h}$ after transfection. Fixed cells were stained with mouse anti-Flag and costained with anti-mouse Alexa 568. Nuclei were visualized using DAPI counterstains as indicated. Differential interference contrast (DIC) imaging demarcates cytoplasmic boundaries. Wild-type FUS (wtFUS) and FUS ${ }^{\mathrm{QB}^{-}}$, FUS ${ }_{-}{ }_{-}, \mathrm{FUS}^{\mathrm{H}}{ }_{-}$, and FUS ${ }^{\mathrm{L}}$-expressing calls are shown, as indicated at the left. White arrows indicate typical nuclear and cytoplasmic aggregates. 
mentioned above, we previously identified a number of putative FUS targets, one of which was MECP2 (Tan et al. 2012). Given that MECP2 has other features of FUS-regulated genes-e.g., potential FUS-RNA interaction motifs and an exceptionally long intron (see Fig. 2A; Lagier-Tourenne et al. 2012; Bagga and D'Antonio 2013; Takahama and Oyoshi 2013) — we decided to examine whether expression of the FUS mutant proteins affects MECP2 expression. For this, we transfected U87 cells with wild-type or mutant FUS expression plasmids and then analyzed levels of MECP2e1 and MECP2e2 mRNAs by RT-PCR. Unexpectedly, increasing amounts of the FUS $^{\mathrm{C}}$ derivative (but not wild-type FUS) (see below) resulted in a slight decrease in $e 2$ mRNA but a striking (>15-fold) increase in the e1 isoform (Fig. 2B). This behavior was not unique to $\mathrm{FUS}^{\mathrm{C}}$, as expression of $\mathrm{FUS}^{\mathrm{H}}$ gave rise to similar changes in MECP2 expression (Fig. 2C, cf. wild-type FUS signal in lanes 3 and 5,6). The nuclear-excluded FUS ${ }^{\mathrm{L}}$ derivative also enhanced $e 1$ mRNA accumulation but to a lower extent (Fig. 2C, cf. wild-type FUS signal in lanes 3 and 7). On the other hand, the recessive FUS $^{\mathrm{Q}}$ behaved indistinguishably from wild-type FUS, which increased total MECP2 mRNA levels only slightly (see also Tan et al. 2012) but had no differential effect on the $e 1$ and $e 2$ isoforms (Fig. 2C [cf. lanes 3 and 4], see also D). Western blots with anti-Flag antibodies confirmed equal expression of all the FUS derivatives, while Western blot with anti-FUS antibodies indicated that the exogenous proteins were expressed at comparable levels relative to endogenous FUS (Supplemental Fig. 1a,b). Confirming and extending these results, a time course with FUS ${ }^{\mathrm{C}}$ showed that a significant increase in $e 1$ was apparent $12 \mathrm{~h}$ after transfection, and e1 levels increased strongly up to at least $36 \mathrm{~h}$ (Fig. 2D). Western blots revealed corresponding increases in FUS ${ }^{\mathrm{C}}$ protein accumulation (Supplemental Fig. 1b). Again, as observed previously (Tan et al. 2012), wild-type FUS produced only a modest increase in both isoforms (Fig. 2D, cf. lanes 1 and 3), while FUS siRNA reduced accumulation of both MECP2 mRNAs (Fig. 2D, lane 4).

\section{FUS ALS mutations do not impact MECP2 transcription but enhance mRNA stability}

We next wished to investigate the molecular basis for the greatly enhanced accumulation of the $e 1$ isoform. One possibility was that the mutant FUS proteins, in addition to altering splicing, also increased MECP2 transcription much more effectively than did wild-type FUS. To investigate this, we isolated RNA from wild-type FUS and FUS ${ }^{\mathrm{C}}$ transfected U87 cells and performed RT-PCR with several pairs of MECP2 intron primers as a measure of transcription. This analysis revealed that equivalent amounts of MECP2 pre-mRNA were produced in wild-type FUS and mutant FUS ${ }^{\mathrm{C}}$ transfected cells (Supplemental Fig. 2; data not shown), indicating that MECP2 transcription was not affected by the FUS ${ }^{\mathrm{C}}$ mutation.

Another possibility to explain the increased levels of $M E C P 2$ mRNA was that the FUS mutations affected MECP2 mRNA stability. To address this, we performed an actinomycin-D (ActD) chase experiment with U87 cells transfected with wild-type FUS, FUS ${ }^{\mathrm{C}}$, or control

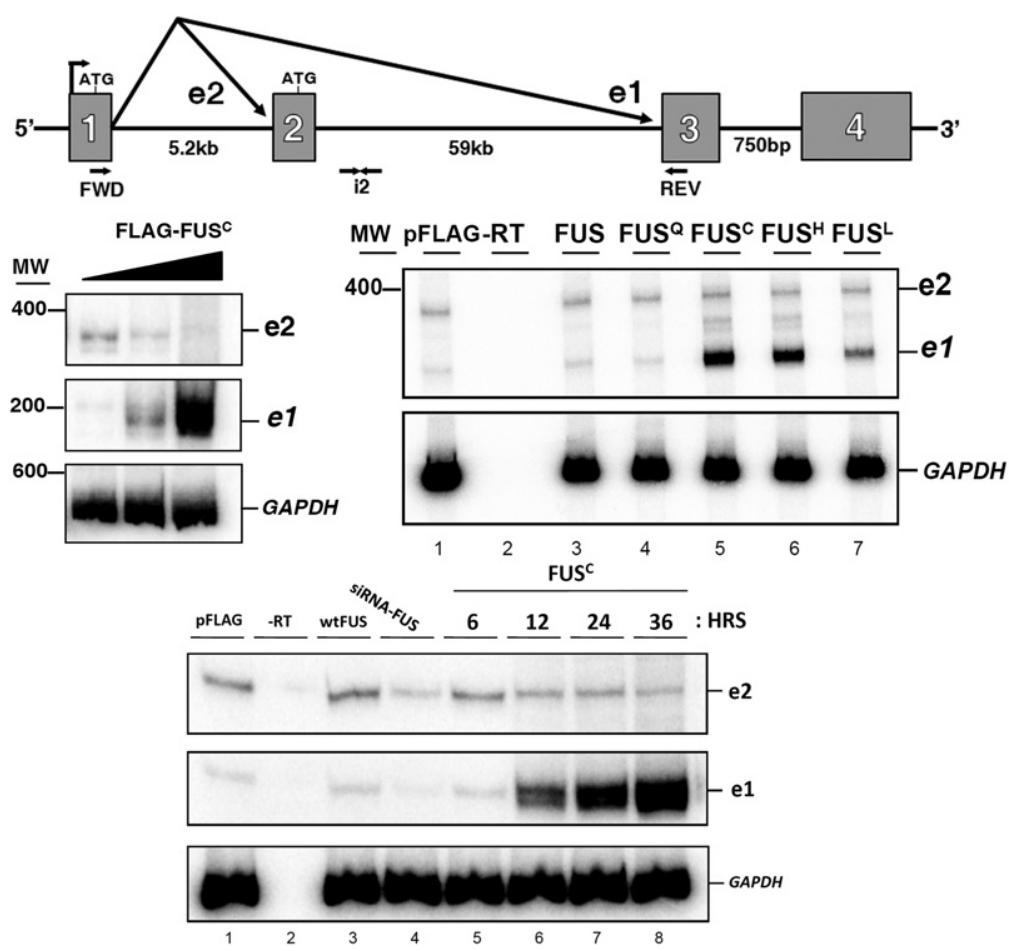

Figure 2. FUS ${ }^{\mathrm{C}}$ and other ALS mutant FUS proteins induce aberrant splicing and accumulation of $M E C P 2$ transcripts. (A) Schematic diagram of the MECP2 gene. Exons 1-4 are indicated by gray boxes, introns are indicated by a thick black line, and lengths are indicated below. MECP2 splicing is illustrated by a branched arrow pointing to target exons for fulllength transcript e2 or alternatively spliced isoform e1. Primer pairs used for RT-PCR are indicated relative to the target sequences. ATG start codons are indicated. The transcription start site (TSS) is designated by a right arrow $5^{\prime}$ of exon 1 . Intron sizes (in base pairs) are indicated. (B) RT-PCR of MECP2 mRNAs from U87 cells transfected with a FUS ${ }^{\mathrm{C}}$ expression plasmid. The black triangle indicates increasing concentrations $(0.25,0.5$, and $1 \mu \mathrm{g})$ of plasmid harvested at $24 \mathrm{~h}$. (C) RT-PCR of MECP2 mRNA from U87 cells transfected with pFlag-empty-expressing, wild-type FUS-expressing (wtFUS), and FUS ${ }^{\mathrm{Q}}, \mathrm{FUS}^{\mathrm{C}}, \mathrm{FUS}^{\mathrm{H}}$, and FUS ${ }^{\mathrm{L}}$ ALS mutant-expressing plasmids. All cells were harvested at 24 h. (D) Time-course RT-PCR of MECP2 mRNA from U87 cells. (Lane 1) Transfection with pFlag alone. (Lane 2) Cells transfected with pFlag but no reverse transcription added in RT-PCR. (Lanes 3,4) Wild-type FUS and siRNA-FUS transfected cells harvested at $24 \mathrm{~h}$ post-transfection. (Lanes 5-8) FUS $^{\mathrm{C}}$ transfected cells harvested at $6,12,24$, and

$36 \mathrm{~h}$ post-transfection, as indicated. In all panels, ${ }^{32} \mathrm{P}$ RT-PCR was performed, and results were visualized using phosphor screens and ImageQuant software. 
(empty) vectors. After $12 \mathrm{~h}$ post-transfection, ActD was added to the medium, cells were incubated for additional times up to $24 \mathrm{~h}$, and MECP2e 1 and MECP2e $2 \mathrm{mRNA}$ levels were analyzed by RT-PCR as above (Fig. 3A, quantitation of multiple experiments in B for $e 2$ isoform and in $\mathrm{C}$ for $e 1$ isoform). In both vector alone and wild-type FUS transfected cells, both isoforms were relatively unstable, with half-lives of 1-2 h. In contrast, in FUS ${ }^{\mathrm{C}}$ transfected cells, both $e 2$ and $e 1$ mRNAs were significantly more long-lived (Fig. 3B,C, FUS ${ }^{\mathrm{C}}$, solid black line). Indeed, an especially striking increase in $e 1$ mRNA stability was observed such that more than nearly half the time 0 amounts remained after $24 \mathrm{~h}$. These results provide strong evidence that the enhanced accumulation of $e 1$ mRNA brought about by the expression of FUS ${ }^{\mathrm{C}}$ and likely the other FUS mutant proteins reflected increased mRNA stability.

\section{MeCP2 protein levels are reduced in cells expressing FUS ALS mutant derivatives}

The above results showing greatly increased levels of MECP2e 1 mRNA in cells expressing FUS mutant proteins suggested that MeCP2 protein levels would likewise be increased. To address this, we expressed wild-type FUS or FUS mutant derivatives in U87 cells and then performed Western blot analysis with cell lysates to measure MeCP2 protein accumulation. (The antibody used recognizes both the $e 1$ and $e 2$ isoforms, which are very similar in size and are not resolved by SDS-PAGE.) Unexpectedly, $\mathrm{MeCP} 2$ protein levels were greatly reduced in cells expressing FUS ${ }^{\mathrm{C}}, \mathrm{FUS}^{\mathrm{H}}$, and $\mathrm{FUS}^{\mathrm{L}}$ derivatives but, in keeping with their lack of effect on mRNA levels, not in cells expressing wild-type FUS or the FUS ${ }^{\mathrm{Q}}$ derivative (Fig. 4, top panel). Anti-Flag Western blots revealed that all FUS derivatives accumulated to equivalent levels
(Fig. 4, middle panel). Thus, despite leading to increased MECP2 mRNA accumulation, three FUS ALS mutations resulted in reduced levels of $\mathrm{MeCP} 2$ protein.

\section{FUS $^{C}$ protein is insoluble and} sequesters MECP2e1 mRNA

We next wished to determine how an ALS mutant FUS protein can on the one hand increase MECP2 mRNA levels while on the other repress MeCP2 protein accumulation. To address this, we first investigated properties of FUS proteins and MECP2 mRNA by biochemical fractionation. To this end, U87 cells were transfected with wildtype FUS or FUS ${ }^{C}$ expression plasmids or empty vector. After $36 \mathrm{~h}$, cells were harvested and extracted with a buffer containing $1 \% \mathrm{NP}-40$ plus $150 \mathrm{mM} \mathrm{NaCl}$ and separated into soluble and insoluble fractions. The insoluble pellet fraction was further extracted with buffers containing low concentrations of denaturants, such as $0.1 \mathrm{M}$ urea. These fractions were first analyzed by Western blot using anti-Flag antibodies (Fig. 5A). Interestingly, while wildtype FUS was predominantly in the soluble fraction (Fig. $5 \mathrm{~A}$, lane 2), FUS $^{\mathrm{C}}$ was detected almost exclusively in the insoluble fraction but was largely solubilized with the urea-containing buffer (Fig. 5A, cf. lanes 3 and 6).

We next examined the localization of MECP2 mRNA in both the insoluble fractions and the soluble fractions following immunoprecipitation with anti-Flag antibodies by RT-PCR. In the vector-alone transfected cells, very small amounts of MECP2 mRNA were detected in the insoluble fraction, and, as expected, nothing was detected in the immunoprecipitations (Fig. 5B, bottom panel, lanes 1,2) from either the NP-40-soluble fraction or the urea extract of the insoluble fraction (Fig. 5B, cf. lane 2 in top and bottom panels). In the extracts from wild-type FUS-transfected cells, only low levels of MECP2 mRNA were found
A
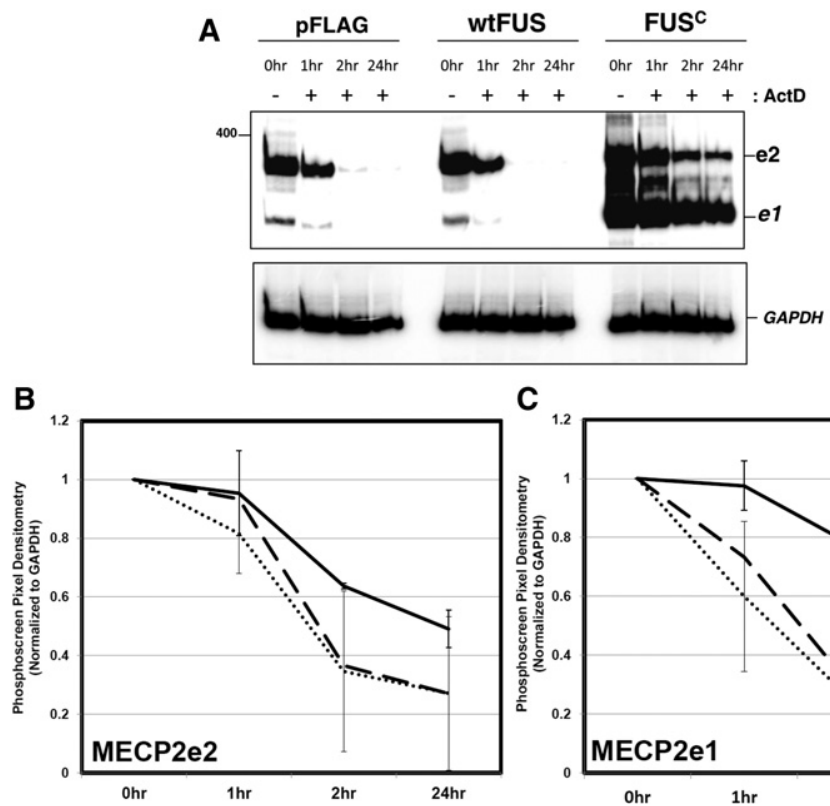

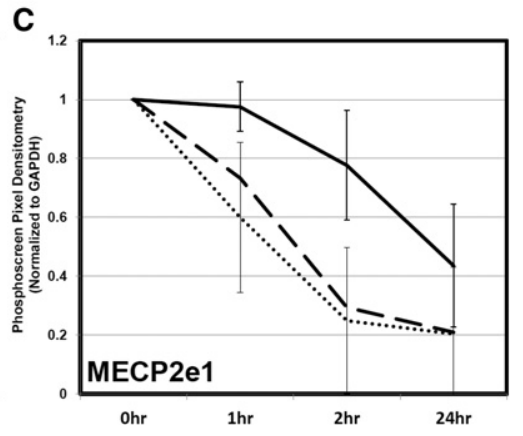

Figure 3. FUS $^{\mathrm{C}}$ enhances $M E C P 2 e 1 \mathrm{mRNA}$ stability. (A) MECP2e1 mRNA stability assay in pFlag control, wild-type FUS (wtFUS), and mutant FUS ${ }^{\mathrm{C}}$ transfected U87 cells. RT-PCR time course of $M E C P 2$ mRNA extracted from transfected cells harvested at $0,1,2$, and $24 \mathrm{~h}$ after ActD addition. ActD was added $12 \mathrm{~h}$ post-transfection. ${ }^{32} \mathrm{P}$ RT-PCR was performed and visualized as in Figure 2. MECP2e2 $(B)$ and $M E C P 2 e 1(C)$ summary and quantitation of RT-PCR data. The dashed line indicates empty vector transfected cells, the dotted line specifies wildtype FUS, and the solid line denotes the FUS ${ }^{\mathrm{C}}$ mutant. MECP2 isoform band intensity was averaged over three experiments per time point. Error bars represent standard deviation. The $Y$-axis indicates pixel densitometry normalized to GAPDH, and the $X$-axis shows time points. 


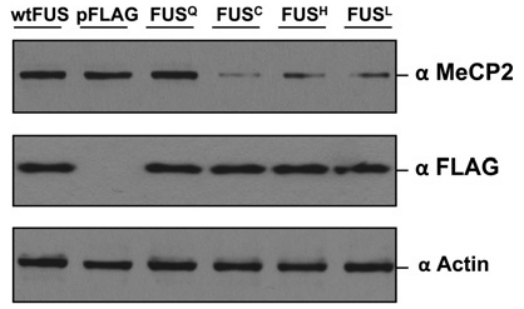

Figure 4. Multiple FUS ALS mutant derivatives reduce MeCP2 protein levels. U87 cells were transfected with wild-type FUS (wtFUS), pFlag, FUS ${ }^{\mathrm{Q}}$, FUS ${ }^{\mathrm{C}}$, FUS ${ }^{\mathrm{H}}$, and $\mathrm{FUS}^{\mathrm{L}}$ plasmids and harvested after $24 \mathrm{~h}$. Cells were lysed in sample buffer and boiled, and proteins were resolved by SDS-PAGE. Blots were developed with anti-MeCP2 (top panel), anti-Flag (middle panel), and antiActin (bottom panel) antibodies.

in the insoluble fraction (Fig. 5B, bottom panel, lane 4). In the NP-40-soluble fraction, both $e 1$ and $e 2$ mRNAs immunoprecipitated with FUS at very low levels, although more $e 1$ than $e 2$ mRNA was detected. As expected, no wild-type FUS-associated MECP2 mRNA was detected in the urea extract of the insoluble fraction (Fig. 5B, lane 5, bottom panel).

Strikingly different results were observed with the FUS ${ }^{\mathrm{C}}$ transfected cells. In the NP-40 fractions, $\sim 65 \%$ of $M E C P 2$ mRNA, almost exclusively $e 1$, was in the insoluble pellet (Fig. 5B, top panel, lane 7), which is in contrast to its behavior in the presence of wild-type FUS. Smaller amounts, similar to those observed with wild-type FUS, were detected in the immunoprecipitation from the soluble fraction (Fig. 5B, top panel, cf. lanes 5 and 8). However, in the urea-extracted samples, the amount in the insoluble fraction was notably reduced, and significant amounts of $e 1$ transcript were observed associated with $\mathrm{FUS}^{\mathrm{C}}$ in the immunoprecipitation (Fig. 5B, cf. the el signal in lane 7 in the top panel, the el signal in lane 7 in the bottom panel, and FUS ${ }^{C}$ IP in lane 8 in the bottom panel). These results indicate that much of the MECP2 mRNA produced in the presence of FUS ${ }^{\mathrm{C}}$ was associated with the mutant protein in an insoluble fraction. Not all mRNAs behave in this manner; for example, IGFBP3 mRNA was not found associated with FUS ${ }^{\mathrm{C}}$ (Supplemental Fig. 3).

\section{MECP2 mRNA colocalizes with FUS ${ }^{C}$ in cytoplasmic aggregates}

The above results provided evidence that MECP2 transcripts associate with an insoluble form of FUS ${ }^{\mathrm{C}}$. We therefore hypothesized that this reflects localization of MECP2 mRNAs, specifically the $e 1$ isoform, in the FUS ${ }^{\mathrm{C}}$ cytoplasmic aggregates that we and others have observed (see above). To test this, we designed fluorescent in situ hybridization (FISH) probes to localize MECP2 mRNA in intact cells. U87 cells were transfected with Flag-tagged wild-type FUS- or FUS ${ }^{\mathrm{C}}$-expressing plasmids, and, after $48 \mathrm{~h}$, cells were fixed and first immunostained with anti-Flag antibodies and subsequently hybridized with the MECP2 mRNA FISH probes. As expected, wildtype FUS (Fig. 6A, red) was entirely localized in the nucle- us, with limited overlap with MECP2 RNA (note that $M E C P 2$ mRNA is detected primarily in the nucleus, likely reflecting its diffuse distribution in the cytoplasm) (Fig. $6 \mathrm{~A}$, green). In contrast, FUS $^{\mathrm{C}}$, also as expected, was
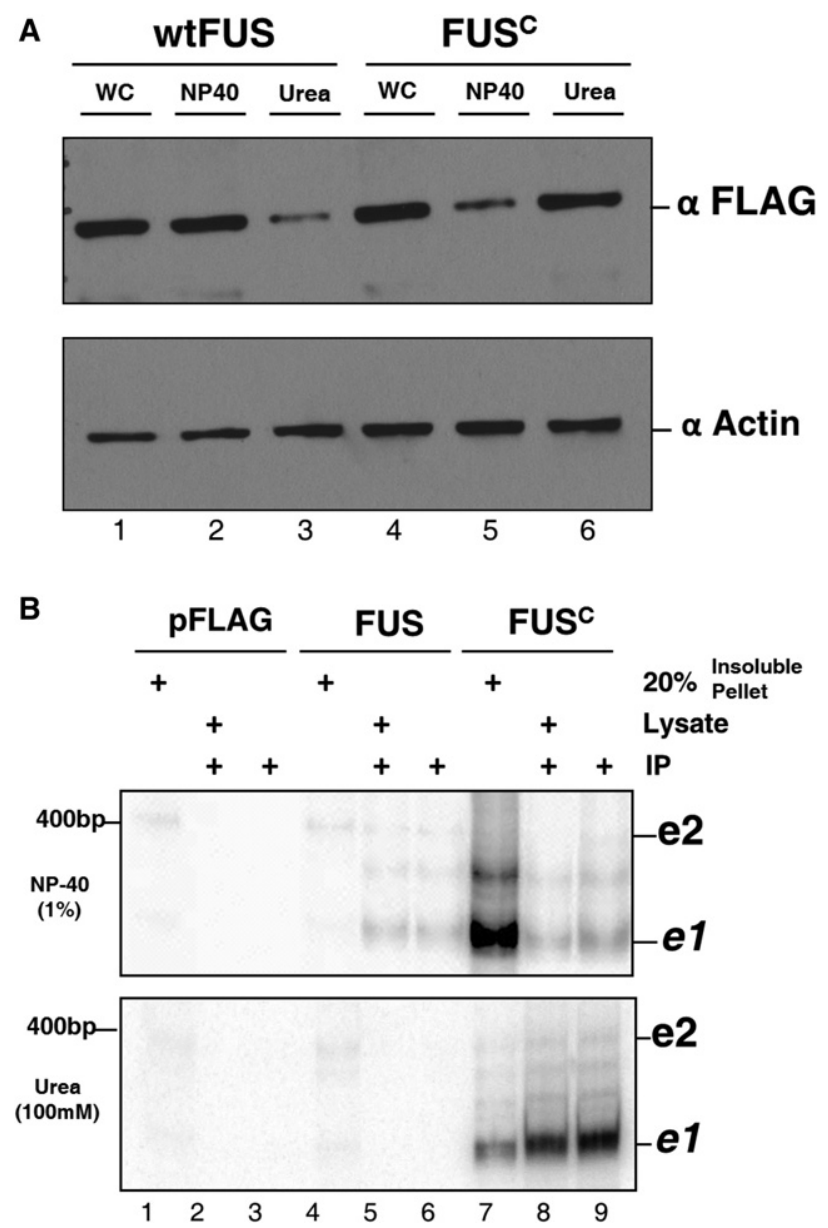

Figure 5. FUS ${ }^{\mathrm{C}}$ is largely insoluble and sequesters $M E C P 2 e 1$ mRNA. (A) U87 cells were transfected with wild-type FUS (wtFUS), and FUS ${ }^{\mathrm{C}}$ plasmids were harvested after $36 \mathrm{~h}$. Cell extracts were prepared, and the insoluble fraction was extracted with urea-containing buffer as described in the Materials and Methods. Aliquots of each sample were resolved with SDSPAGE and subjected to Western blotting. As indicated, wildtype FUS is depicted in the first three lanes, and $\mathrm{FUS}^{\mathrm{C}}$ is shown in the second three lanes. In each set, lane 1 is the total wholecell lysate (WC), lane 2 is the NP40-soluble supernatant, and lane 3 is the $0.1 \mathrm{M}$ urea-soluble fraction. Western blots were developed with anti-Flag (top panel) and anti-Actin (bottom panel) antibodies as indicated. $(B)$ Cell extracts from transfected cells as in $A$ were analyzed for the presence of $M E C P 2$ RNA by RTPCR. The results are displayed as sets of three lanes for each transfected plasmid: pFlag (left, lanes 1-3), wild-type FUS (middle, lanes 4-6), and FUS ${ }^{\mathrm{C}}$ (right, lanes 7-9). (Lanes 1,4,7) Twenty percent of the total volume of insoluble pellet fraction following NP40 cell lysis (top panel) or urea buffer extraction of the NP40 pellet (bottom panel). (Lanes 2,5,8) Flag immunoprecipitation of NP40 supernatants (top panel) or urea buffer-extracted supernatants derived from NP40-lysed U87 cellular pellets (bottom panel). (Lanes 3,6,9) Supernatants of immunoprecipitations displayed in lanes 2,5 , and 8 , respectively. 
A

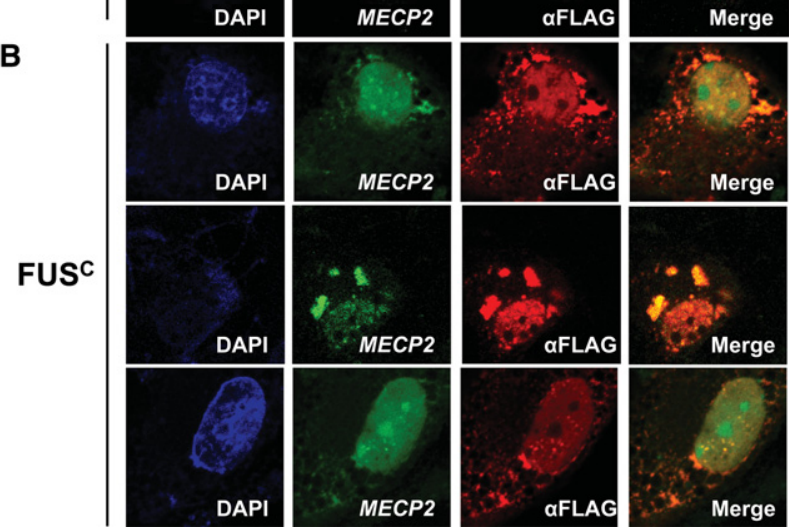

Figure 6. MECP2 mRNA colocalizes with $\mathrm{FUS}^{\mathrm{C}}$ in cytoplasmic inclusions. (A) FISH analysis of MECP2 mRNA in wild-type FUS (wtFUS) transfected U87 cells. Cells were fixed at $36 \mathrm{~h}$ post-transfection, exposed to biotinylated-MECP2 RNA probes (second panel; Oregon green 514), and stained with anti-Flag antibodies (third panel; red; Alexa 568); nuclei were visualized with DAPI (first panel; blue). The merged panel shows overlap of all channels. (B) FUS ${ }^{C}$ transfected cells were analyzed exactly as in $A$.

detected in cytoplasmic aggregates with reduced nuclear accumulation (Fig. 6B). Strikingly, MECP2 mRNA (Fig. $6 \mathrm{~B}$, green) strongly colocalized with the FUS ${ }^{\mathrm{C}}$ aggregates (Fig. 6B, merge). DNase and RNase treatments demonstrated that the $M E C P 2$ probe signals were derived from RNA (Supplemental Fig. 4). Extending these results, we found that the FUS ${ }^{\mathrm{C}}$ aggregates contain GRIA1 mRNA, a known FUS target encoding a glutamate receptor that was determined to be altered in ALS patient neural tissues (Supplemental Fig. 5; Virgo et al. 1996; Petri et al. 2004; Udagawa et al. 2015). However, FISH with probes for IGFBP3 and NF-H mRNAs provided evidence that these mRNAs did not colocalize with the FUS ${ }^{\mathrm{C}}$ aggregates (Supplemental Fig. 6a,b, respectively), providing evidence for the specificity of the MECP2 mRNA-FUS ${ }^{\mathrm{C}}$ colocalization. Taken together, our results indicate that MECP2 mRNA localizes to insoluble cytoplasmic aggregates together with the FUS ${ }^{\mathrm{C}}$ mutant protein and provide a plausible mechanism for the observed enhanced mRNA stability and reduced translational output.

\section{Discussion}

ALS is a complex, genetically and clinically diverse neurodegenerative disease characterized by the progressive loss of neuronal populations and, frequently, the appearance of cytoplasmic protein aggregates. It is currently unknown how these ALS-associated aggregates affect cellular function or how they contribute to disease. Our previous studies identifying putative FUS target gene promoters allowed us to analyze how ALS-related FUS mutations, known to result in aggregate formation, might affect gene expression. We report here that cells expressing FUS derivatives with ALS mutations increased MECP2e1 mRNA isoform abundance through altered splicing and enhanced mRNA stability. Further analysis revealed that $\mathrm{MeCP} 2$ protein levels were sharply reduced in these cells, correlating with localization of MECP2 mRNA into insoluble FUS-containing cytoplasmic aggregates. Based on these results, we propose that the biochemical changes in the FUS protein that are brought about by mutation alter neuronal gene expression by disrupting mRNA processing, stability, and translatability. Below we discuss possible mechanistic underpinnings for these findings as well as the implications that our results have for ALS and possibly other neuronal diseases.

FUS naturally functions in the nucleus in both transcription and splicing. Thus, reduced levels of nuclear FUS resulting from accumulation of mutant FUS in cytoplasmic aggregates may alter either of these processes. For example, we showed previously that FUS knockdown affected expression levels of target genes, in some cases reducing expression while in other cases increasing it (Tan et al. 2012). Likewise, global analyses of FUS knockdown cells have revealed changes in alternative RNA processing, consistent with the expected function of FUS in splicing (Nakaya et al. 2013; Orozco and Edbauer 2013; Sun et al. 2015). These effects could reflect mechanistically changes in the activity of FUS-interacting proteins; e.g., transcription factors TFIID and RNAP II, splicing factor SRSF10 (Tan and Manley 2009), and/or decreased occupancy on target RNA/DNA sequences (Ishigaki et al. 2012; Rogelj et al. 2012). Indeed, changes in phosphorylation of the RNAP II large subunit regulatory domain, the C-terminal domain (CTD), have been reported in both FUS knockdown cells and ALS patient fibroblasts, leading to global changes in gene expression (Schwartz et al. 2012; 2014) and consistent with the known roles of the CTD in transcription and mRNA processing (for review, see Hsin and Manley 2012). However, changes in gene expression resulting solely from reduced levels of nuclear FUS are insufficient to explain fully changes that occur in the presence of ALS mutant FUS. For example, FUS knockdown in U87 cells had only a modest effect on MECP2 expression, likely reflecting reduced transcription (Tan et al. 2012). This is in sharp contrast to the changes brought about by mutant FUS described here, which thus must reflect gain of function due to the presence of the mutant protein.

What causes the gene expression changes brought about by accumulation of FUS mutant proteins? We detected changes in MECP2 mRNA splicing, stability, and translation caused specifically by expression of FUS mutant derivatives. We propose that these are all due at least in part to sequestration of FUS in cytoplasmic aggregates. With regard to the change in splicing, as argued above, this cannot be due solely to reduced nuclear FUS concentrations. We thus suggest that it instead reflects sequestration of additional splicing factors in the FUS aggregates. For example, 
defects in the spliceosomal snRNP maturation cycle have been observed in the presence of ALS mutant FUS derivatives. This involves interactions with the SMN protein that functions in snRNP assembly and with U1 snRNP itself (Yamazaki et al. 2012; Gerbino et al. 2013). These interactions are altered by ALS mutations, leading to decreased U1 snRNP assembly and abnormal accumulation of U1 snRNA in the cytoplasm (Sun et al. 2015; Yu et al. 2015). Our own results also indicate that a fraction of U1 snRNA localizes abnormally in the cytoplasm in the presence of mutant FUS derivatives, accumulating with FUS ${ }^{\mathrm{C}}$ in cytoplasmic aggregates (TH Coady and JL Manley, unpubl.). The resulting changes in nuclear U1 snRNP levels and possibly other splicing factors such as hnRNPA1/2 (Takanashi and Yamaguchi 2014) would likely contribute to altered splicing patterns. Additional properties of mutant FUS may also contribute to deregulated splicing. For example, global analyses indicated that mutant FUS derivatives displayed pronounced reduction in intronic binding and enhanced association with $3^{\prime}$ untranslated regions (UTRs) as compared with wild-type FUS (Hoell et al. 2011). Coupled with work suggesting that exceptionally long introns may be preferential targets of FUS (Polymenidou et al. 2011; Lagier-Tourenne et al. 2012), these studies together suggest how mutant FUS proteins can both alter splicing of MECP2 mRNA and associate with it in cytoplasmic aggregates.

The above discussion describes mechanisms by which MECP2 mRNA alternative splicing is dysregulated by mutant FUS proteins. However, the effect on splicing that we observed was relatively modest compared with the substantial increase in $e 1$ mRNA stability and decrease in MeCP2 protein levels that we detected. We suggest that both of these effects, like the splicing defect, result from the mutant FUS-containing aggregates but here are due to the physical sequestration of MECP2 mRNA in a manner that blocks both mRNA turnover and translation. It is important to note that cytoplasmic aggregates are a common feature of ALS (Blokhuis et al. 2013; Li et al. 2013), yet it has not been clear what function, if any, these aggregates play in disease pathogenesis. Our results thus demonstrate that such aggregates can indeed play a critical function, which is disrupting expression of specific genes.

How is MECP2 mRNA targeted to the mutant FUS aggregates? Studies on the composition and function of FUS aggregates containing the FUS ${ }^{\mathrm{C}}$ mutant found their formation to be dependent on the presence of the FUS RNA-binding subdomain, indicating that association with RNA is critical (Daigle et al. 2013). Additional insight likely reflects the shift of FUS mutant binding from intronic sequences to sites in 3' UTRs (Hoell et al. 2011). The MECP2 3' UTR is unusual in that it can be exceptionally long (Coy et al. 1999; Balmer et al. 2003) and contains multiple evolutionarily conserved motifs that have been suggested to influence stability and translation efficiency (Newnham et al. 2010; Bagga and D'Antonio 2013). Notably, the $e 1$ mRNA isoform, which accumulates in the presence of mutant FUS, tends to have the longest $3^{\prime}$ UTR / 10 $\mathrm{kb}$, reflecting alternative polyadenylation) (Samaco et al. 2004) and would thus be most likely to contain sequence motifs that facilitate targeting to the FUS aggregates. Indeed, it is possible that such sequences contribute to determining which mRNAs are sequestered by cytoplasmic aggregates in ALS and perhaps other neurodegenerative disorders.

FUS aggregates are known to contain additional proteins and RNAs. For example, in addition to splicing-related factors, they have been reported to be enriched in cell stress proteins and proteins involved in translation (Dormann and Haass 2013; Vanderweyde et al. 2013). Notably, both wild-type and mutant FUS were found to associate with the tumor suppressor protein adenomatous polyposis coli (APC), which is known to form cytoplasmic RNA-containing particles (Yasuda et al. 2013). Surprisingly, translation was detected in APC-RNPs that were associated with not only wild-type but also mutant FUS. This is in contrast to our results indicating that MECP2 mRNA is translationally silent. The basis for the discrepancy is unclear. One explanation is that MECP2 mRNA is indeed translated, but the protein then rapidly degraded. This seems unlikely, as it would require a mechanism to target for degradation MeCP2 protein made in the presence of mutant but not wild-type FUS. Another possibility is that different mRNAs behave differently; e.g., MECP2 mRNA with its exceptionally long $3^{\prime}$ UTR may be more subject to translational silencing. Finally, there may be differences in the APC-RNPs analyzed previously and the aggregates detected in our study. For example, the former were analyzed in mouse NIH3T3 and found to associate with wild-type as well as mutant FUS, while we detected no evidence of aggregates in the presence of wild-type FUS in human U87 cells.

The results presented here establish a new mechanism by which ALS mutant FUS derivatives can impact cellular function and show how the cytoplasmic aggregates characteristic of ALS can indeed exert a toxic gain of function. However, an intriguing question is whether the specific example that we analyzed here-dysregulation of MECP2 expression-is directly relevant to ALS. A clue stems from the realization that glia and astrocytes contribute to the pathology of both ALS and Rett syndrome (Lioy et al. 2011; Phatnani et al. 2013; Yasui et al. 2013). A common trait shared between ALS and Rett syndrome is a non-cell-autonomous-mediated neuronal death, and glial cells expressing either ALS mutant proteins or reduced levels of MeCP2 secrete a neurotoxin that leads to inhibition of dendritic complexity and neuron death (Ballas et al. 2009). Additionally, recent studies have shown that dysregulation of MeCP2 protein, similar to FUS, preferentially affects expression of long genes (Sugino et al. 2014; Gabel et al. 2015). Intriguingly, following expression of a Rett syndrome-associated MeCP2 mutant in a mouse model, the greatest change in gene expression was observed in the Netrin G1 (NTNG1) gene (Gabel et al. 2015), and NTNG1 has also been repeatedly identified as a top candidate for FUS-mediated pathological splicing in ALS /Orozco and Edbauer 2013). While further work is required, specifically with disease-relevant ALS patient samples, these studies together point to a possible link between MECP2 dysfunction and ALS pathology. 
In summary, we showed that several different ALS mutations in FUS all result in profound dysregulation of expression of a FUS target gene, altering mRNA splicing, stability, and translation. While future studies will be required to elucidate details of the underlying mechanisms and whether these defects in expression play a significant role in disease pathology, our results established how the cytoplasmic protein aggregates characteristic of ALS and other neurodegenerative diseases can negatively impact gene expression at multiple levels.

\section{Materials and methods}

Plasmids, transfections, and U87 cell harvest

FUS cDNA was cloned into pFlag14 NotI and BamHI restriction sites. ALS mutations were incorporated by insertion mutagenesis. Plasmid preparations were purified using Qiagen MidiPrep columns and resuspended in TE (pH 8.0). Transfections were performed using U87 cells plated at a density of 800,000 cells in RPMI (Invitrogen) and 10\% FBS in 100-mm dishes (Falcon). Plasmid transfections were accomplished using a ratio of $1 \mu \mathrm{g}$ of DNA to $2 \mu \mathrm{L}$ of Lipofectamine 2000 (Invitrogen) dilutions into $800-\mu \mathrm{L}$ total volume of OptiMEM medium (Invitrogen). Transfection mixtures were incubated for $90 \mathrm{sec}$ and then added drop-wise onto cells. The medium was removed $6 \mathrm{~h}$ post-transfection, cells were washed with PBS, and the medium was replaced with DMEM (Invitrogen) supplemented with $10 \%$ FBS. At the indicated times, cells were washed, harvested, and resuspended in PBS.

\section{RNA analysis}

Total cell RNA was obtained by TRIzol (Ambion) extraction, and supernatants were treated with DNase I (New England Biolabs) prior to ethanol precipitation. After resuspension in $30 \mu \mathrm{L}$ of $\mathrm{H}_{2} \mathrm{O}$, RNA concentrations were determined using a NanoDrop spectrophotometer. To analyze polyadenylated mRNA, resuspended RNA was hybridized with oligo-dT (Invitrogen). For analysis of transcription via intron probe sets, a random hexamer (Invitrogen) was used as indicated. Prior to reverse transcription, $500 \mathrm{ng}$ of RNA was combined with final concentrations of $1.5 \mathrm{mM}$ dNTPs and $2.5 \mu \mathrm{M}$ oligo-dT (or $50 \mu \mathrm{M}$ hexamer) in $15 \mu \mathrm{L}$ of $\mathrm{H}_{2} \mathrm{O}$. Tubes were heated for $5 \mathrm{~min}$ to $65^{\circ} \mathrm{C}$ and then rapidly cooled for $10 \mathrm{~min}$ in ice water. Reverse transcription reactions (20- $\mu \mathrm{L}$ total volume) were performed with $4 \mu \mathrm{L}$ of Maxima buffer, $0.2 \mu \mathrm{L}$ of RNase inhibitors, and $0.5 \mu \mathrm{L}$ of Maxima RT enzyme. Reverse transcription was performed in three steps; $10 \mathrm{~min}$ at $25^{\circ} \mathrm{C}$, $50 \mathrm{~min}$ at $42^{\circ} \mathrm{C}$, and, finally, $10 \mathrm{~min}$ at $72^{\circ} \mathrm{C}$. PCR was performed using $3 \mu \mathrm{L}$ from reverse transcription reactions in a linear amplification (16-cycle) PCR using $0.25 \mu \mathrm{L}$ of Taq polymerase (Invitrogen) plus ${ }^{32} \mathrm{P}$ dCTP $(0.6 \mu \mathrm{Ci}$; Perkin-Elmer $)$ in a final volume of $25 \mu \mathrm{L}$. MECP2 PCR primer sequences for $e 2$ and $e 1$ mRNA isoforms were as described in Kriaucionis and Bird (2004). Products were visualized by electrophoresis in $1 \times$ TBE buffer through $6 \%(\mathrm{w} / \mathrm{v})$ polyacrylamide gels (29:1, Acryl:Bis-Acryl), dried, and exposed to Kodak Scintillation screens. Images were recorded via GE Typhoon FLA7000 and GE phosphor-capture software. Quantitation was performed using ImageQuant software. RNA isoform bands were selected, total pixel areas were kept constant between lanes, and background subtraction was included before quantitation. Experiments were performed in triplicate, averages were calculated, standard deviations are demarcated as error bars, and significance was determined via Student's $t$-test.
mRNA stability

U87 cells were trypsinized, and 800,000 cells were plated into two $100-\mathrm{mm}$ dishes for each transfection. Cells were transfected $12 \mathrm{~h}$ later with plasmids as above. The medium was then replaced with either normal medium or medium with $2.5 \mu \mathrm{g} / \mathrm{mL}$ ActD (Sigma). Cells were harvested at the indicated times, and total RNA was purified and analyzed as above. For quantitation, the band intensities of both MECP2 mRNA isoforms at the time of ActD addition was set to 1 . Reverse transcription of GAPDH served as a loading control.

\section{Western blots}

For Western blots of whole-cell lysates, cell pellets were dissolved directly into SDS loading buffer. For cell fractions, $5 \times$ SDS loading buffer was added. In both cases, samples were boiled and resolved by SDS-PAGE. Gels were transferred to $0.45 \mu \mathrm{M}$ nitrocellulose (Bio-Rad) for $100 \mathrm{~min}$ with $400 \mathrm{~mA}$ constant. Antibodies were used as follows: Anti-Flag Ms (1:2000; Sigma), anti-FUS H6 Ms (1:1000; Santa Cruz Biotechnology), anti-MeCP2 D4F3 (1:2000; Cell Signaling), and anti-Actin Rb (1:2000; Sigma) were all diluted into $4 \%$ nonfat milk (Lab Scientific) and Tris-buffered saline supplemented with $0.5 \%$ Tween (TBST). Protein bands were visualized using Millipore ECL kit and CL-X Posure X-ray film (Thermo-Scientific).

\section{Cellular biochemical fractionation and immunoprecipitation}

For recombinant Flag immunoprecipitations, 800,000 U87 cells were plated onto four 100-mm dishes, transfected, and harvested as described above. Cell numbers were normalized between experiments. All RNA buffers were treated with DEPC (1:1000; Sigma). Cell pellets were dissolved in "CE $\mathrm{CE}^{+\prime}$ buffer $(10 \mathrm{mM}$ HEPES at $\mathrm{pH}$ 7.6, $60 \mathrm{mM} \mathrm{KCl}, 1 \mathrm{mM}$ EDTA, $1 \mathrm{mM}$ PMSF, $1 \mathrm{mM} \mathrm{DTT}, 0.75 \%$ NP-40, 1× protease inhibitor cocktail [Roche]) and sonicated. Cell extracts were centrifuged in an Eppendorf model 5424 at $10,000 \mathrm{rpm}$ for $20 \mathrm{~min}$ at $4^{\circ} \mathrm{C}$, the supernatant was designated the "soluble" fraction, and the pellet was designated the "insoluble" fraction. Insoluble buffer $(5 \times[\mathrm{w} / \mathrm{v}])(50 \mathrm{mM}$ Tris at $\mathrm{pH} 8.5,200$ $\mathrm{mM} \mathrm{NaCl}, 2 \mathrm{mM} \mathrm{KCl}, 1 \mathrm{mM}$ EDTA, 0.5\% glycerol, $1 \mathrm{mM} \mathrm{PMSF}$, $100 \mathrm{mM}$ urea) was added to pellets, which were dissolved at $37^{\circ} \mathrm{C}$ inside an Autoblot rotator incubator (Thomas Scientific) for $1 \mathrm{~h}$. Immunoprecipitations were initiated using $0.5 \mu \mathrm{L}$ of Flag Ms (Sigma) antibody incubated with soluble or insoluble-solubilized extracts for $1 \mathrm{~h}$ prior to adding $20 \mu \mathrm{L}$ (bed volume) of blocked beads. Protein A Sepharose Fast Flow beads (GE Healthcare Life Sciences) were preblocked for $1 \mathrm{~h}$ using $2 \mu \mathrm{g}$ of ssDNA (Sigma) in TE (pH 7.5) and $0.05 \%(\mathrm{w} / \mathrm{v}) \mathrm{BSA}$ and then washed three times with $\mathrm{CE}^{+}$prior to addition to immunoprecipitation reactions. Soluble and insoluble immunoprecipitations used an orbital motion rocker (Boekel Scientific) and sample agitation conducted at $25^{\circ} \mathrm{C}$. After immunoprecipitation, beads were washed four times with $\mathrm{CE}^{+}$supplemented with $250 \mathrm{mM} \mathrm{NaCl}$. FUS-bound RNAs were extracted by directly adding $800 \mu \mathrm{L}$ of TRizol to the postimmunoprecipitation washed beads. Following centrifugation, the supernatant was treated with DNase I, RNA-precipitated, and analyzed by RT-PCR as described above.

\section{Immunofluorescence/FISH}

U87 cells $(100,000$ cells per milliliter $)$ were plated in $650 \mu \mathrm{L}$ of RPMI onto a sterile $22 \times 22$-mm coverslip (Fisher-Scientific) positioned in the bottom of a well in a six-well dish (Falcon). Adherent cells were washed and incubated in $1 \mathrm{~mL}$ of RPMI-FBS 
medium for $12 \mathrm{~h}$ after initial plating. Transfection ratios were the same as above, but each well contained $800 \mu \mathrm{L}$ of DNA + Lipofectamine + RPMI transfection medium. After $36 \mathrm{~h}$, transfected cells were fixed in $1.5 \%$ formaldehyde for $10 \mathrm{~min}$ at $25^{\circ} \mathrm{C}$, washed with PBS, and then incubated with $130 \mathrm{mM}$ glycine for $5 \mathrm{~min}$ at $25^{\circ} \mathrm{C}$. Samples were blocked in $1 \%$ milk/TBST and then washed with $2 \times$ PBS. FUS protein was visualized with Flag antibody diluted $1: 800$ in $1 \times$ PBS and $0.05 \%$ glycerol at $4^{\circ} \mathrm{C}$. MECP2 and IGFBP3 $N F-H$ biotinylated FISH probes (Invitrogen) were diluted to 0.5 $\mu \mathrm{M}$ in a buffer of $2 \times \mathrm{SSC}, 20 \%$ formamide, and $5 \%$ dextran sulfate in PBS and hybridized overnight at $4^{\circ} \mathrm{C}$ in a humidity chamber. FUS-Flag protein visualization was performed by secondary anti-mouse Alexa 568 (Invitrogen). Biotinylated FISH probe and RNA complexes were detected by high-affinity anti-biotin streptavidin-conjugated Oregon green 514 (Invitrogen). Secondary antibodies were diluted 1:800 (TBST, $0.5 \%[\mathrm{w} / \mathrm{v}]$ milk), vortexed in blocking buffer, and centrifuged at $4000 \mathrm{rpm}$ for $2 \mathrm{~min}$. Nuclear stains used DAPI (Sigma) diluted into McIlvaine's buffer (20 mM citric acid, $160 \mathrm{mM} \mathrm{Na}_{2} \mathrm{PO}_{4}$ at $\mathrm{pH}$ 7.4) and exposed to samples for $10 \mathrm{~min}$. Removal of DAPI and cellular debris was accomplished via PBS wash and then a rapid wash of $2 \mathrm{~mL}$ of TBST with a final wash of $2 \times$ PBS. Coverslips were then mounted onto frosted $22 \times$ 50 -mm microscope slides with $9 \mu \mathrm{L}$ of ProLong Gold anti-fade solution (Life Technologies). Where indicated, DNase I and RNase A were diluted to $1 \mathrm{U}$ and $20 \mu \mathrm{g}$ per $500 \mu \mathrm{L}$ in enzyme-specific buffers, respectively, and added to cells for $10 \mathrm{~min}$ at $25^{\circ} \mathrm{C}$. Reactions were quenched, and sample preparation was as described above. Microscopy was performed using a Zeiss LSM 710 confocal microscopy with Zeiss-Zen software and ImageJ image analysis. Aggregates were analyzed by determining, within the captured cell image, a minimal-maximal level for the intensity of subcytoplasmic Flag/FISH probe staining as a function of pixel height in that particular channel of laser excitation. After establishing the window of threshold staining, the same observational limits were also applied uniformly within experimental replicates. Postthreshold images were analyzed for pixel density via "inclusive" morphometry analysis for resolving aggregate volume.

\section{Acknowledgments}

We thank Veronica Jove and Anna Leone for technical assistance, and other members of the Manley laboratory for their thoughtful comments and discussions. This work was supported by National Institutes of Health grant RO1 GM048259.

\section{References}

Bagga JS, D'Antonio LA. 2013. Role of conserved cis-regulatory elements in the post-transcriptional regulation of the human MECP2 gene involved in autism. Hum Genomics 7: 19.

Ballas N, Lioy DT, Grunseich C, Mandel G. 2009. Non-cell autonomous influence of MeCP2-deficient glia on neuronal dendritic morphology. Nat Neurosci 12: 311-317.

Balmer D, Goldstine J, Rao YM, LaSalle JM. 2003. Elevated methyl-CpG-binding protein 2 expression is acquired during postnatal human brain development and is correlated with alternative polyadenylation. J Mol Med (Berl) 81: 61-68.

Baumer D, Ansorge O, Almeida M, Talbot K. 2010. The role of RNA processing in the pathogenesis of motor neuron degeneration. Expert Rev Mol Med 12: e21.

Belzil VV, Valdmanis PN, Dion PA, Daoud H, Kabashi E, Noreau A, Gauthier J, Hince P, Desjarlais A, Bouchard JP, et al. 2009. Mutations in FUS cause FALS and SALS in French and French Canadian populations. Neurology 73: 1176-1179.
Bentmann E, Neumann M, Tahirovic S, Rodde R, Dormann D, Haass C. 2012. Requirements for stress granule recruitment of fused in sarcoma (FUS) and TAR DNA-binding protein of 43 kDa (TDP-43). J Biol Chem 287: 23079-23094.

Bertolotti A, Lutz Y, Heard DJ, Chambon P, Tora L. 1996. hTAF(II)68, a novel RNA/ssDNA-binding protein with homology to the pro-oncoproteins TLS/FUS and EWS is associated with both TFIID and RNA polymerase II. EMBO $J$ 15: 5022-5031.

Blechingberg J, Luo Y, Bolund L, Damgaard CK, Nielsen AL. 2012. Gene expression responses to FUS, EWS, and TAF15 reduction and stress granule sequestration analyses identifies FET-protein non-redundant functions. PLoS One 7: e46251.

Blokhuis AM, Groen EJ, Koppers M, van den Berg LH, Pasterkamp RJ. 2013. Protein aggregation in amyotrophic lateral sclerosis. Acta Neuropathol 125: 777-794.

Bosco DA, Lemay N, Ko HK, Zhou H, Burke C, Kwiatkowski TJ Jr, Sapp P, McKenna-Yasek D, Brown RH Jr, Hayward LJ. 2010. Mutant FUS proteins that cause amyotrophic lateral sclerosis incorporate into stress granules. Hum Mol Genet 19: 4160-4175.

Buratti E, Dork T, Zuccato E, Pagani F, Romano M, Baralle FE. 2001. Nuclear factor TDP-43 and SR proteins promote in vitro and in vivo CFTR exon 9 skipping. EMBO J 20: 1774-1784.

Calvio C, Neubauer G, Mann M, Lamond AI. 1995. Identification of hnRNP P2 as TLS/FUS using electrospray mass spectrometry. RNA 1: 724-733.

Conte A, Lattante S, Zollino M, Marangi G, Luigetti M, Del Grande A, Servidei S, Trombetta F, Sabatelli M. 2012. P525L FUS mutation is consistently associated with a severe form of juvenile amyotrophic lateral sclerosis. Neuromuscul Disord 22: 73-75.

Coy JF, Sedlacek Z, Bachner D, Delius H, Poustka A. 1999. A complex pattern of evolutionary conservation and alternative polyadenylation within the long $3^{\prime \prime}$-untranslated region of the methyl-CpG-binding protein 2 gene (MeCP2) suggests a regulatory role in gene expression. Hum Mol Genet 8: 1253-1262.

Crozat A, Aman P, Mandahl N, Ron D. 1993. Fusion of CHOP to a novel RNA-binding protein in human myxoid liposarcoma. Nature 363: 640-644.

Cusack SM, Rohn TT, Medeck RJ, Irwin KM, Brown RJ, Mercer LM, Oxford JT. 2004. Suppression of MeCP2 $\beta$ expression inhibits neurite extension in PC12 cells. Exp Cell Res 299: 442-453.

Daigle JG, Lanson NA Jr, Smith RB, Casci I, Maltare A, Monaghan I, Nichols CD, Kryndushkin D, Shewmaker F, Pandey UB. 2013. RNA-binding ability of FUS regulates neurodegeneration, cytoplasmic mislocalization and incorporation into stress granules associated with FUS carrying ALS-linked mutations. Hum Mol Genet 22: 1193-1205.

David CJ, Manley JL. 2010. Alternative pre-mRNA splicing regulation in cancer: pathways and programs unhinged. Genes Dev 24: $2343-2364$.

Dormann D, Haass C. 2013. Fused in sarcoma (FUS): an oncogene goes awry in neurodegeneration. Mol Cell Neurosci 56: 475-486.

Dragich JM, Kim YH, Arnold AP, Schanen NC. 2007. Differential distribution of the MeCP2 splice variants in the postnatal mouse brain. J Comp Neurol 501: 526-542.

Gabel HW, Kinde B, Stroud H, Gilbert CS, Harmin DA, Kastan NR, Hemberg M, Ebert DH, Greenberg ME. 2015. Disruption of DNA-methylation-dependent long gene repression in Rett syndrome. Nature 522: 89-93.

Gerbino V, Carrì MT, Cozzolino M, Achsel T. 2013. Mislocalised FUS mutants stall spliceosomal snRNPs in the cytoplasm. Neurobiol Dis 55: 120-128. 
Hoell JI, Larsson E, Runge S, Nusbaum JD, Duggimpudi S, Farazi TA, Hafner M, Borkhardt A, Sander C, Tuschl T. 2011. RNA targets of wild-type and mutant FET family proteins. Nat Struct Mol Biol 18: 1428-1431.

Hsin JP, Manley JL. 2012. The RNA polymerase II CTD coordinates transcription and RNA processing. Genes Dev 26: 2119-2137.

Ishigaki S, Masuda A, Fujioka Y, Iguchi Y, Katsuno M, Shibata A, Urano F, Sobue G, Ohno K. 2012. Position-dependent FUSRNA interactions regulate alternative splicing events and transcriptions. Sci Rep 2: 529.

Itoh M, Tahimic CG, Ide S, Otsuki A, Sasaoka T, Noguchi S, Oshimura M, Goto Y, Kurimasa A. 2012. Methyl CpG-binding protein isoform MeCP2_e2 is dispensable for Rett syndrome phenotypes but essential for embryo viability and placenta development. J Biol Chem 287: 13859-13867.

Jugloff DG, Jung BP, Purushotham D, Logan R, Eubanks JH. 2005. Increased dendritic complexity and axonal length in cultured mouse cortical neurons overexpressing methyl-CpG-binding protein MeCP2. Neurobiol Dis 19: 18-27.

Kriaucionis S, Bird A. 2004. The major form of MeCP2 has a novel $\mathrm{N}$-terminus generated by alternative splicing. Nucleic Acids Res 32: 1818-1823.

Kwiatkowski TJ Jr, Bosco DA, Leclerc AL, Tamrazian E, Vanderburg CR, Russ C, Davis A, Gilchrist J, Kasarskis EJ, Munsat T, et al. 2009. Mutations in the FUS/TLS gene on chromosome 16 cause familial amyotrophic lateral sclerosis. Science 323: 1205-1208.

Kwon I, Kato M, Xiang S, Wu L, Theodoropoulos P, Mirzaei H, Han T, Xie S, Corden JL, McKnight SL. 2013. Phosphorylation-regulated binding of RNA polymerase II to fibrous polymers of low-complexity domains. Cell 155: 1049-1060.

Lagier-Tourenne C, Polymenidou M, Hutt KR, Vu AQ, Baughn M, Huelga SC, Clutario KM, Ling SC, Liang TY, Mazur C, et al. 2012. Divergent roles of ALS-linked proteins FUS/TLS and TDP-43 intersect in processing long pre-mRNAs. Nat Neurosci 15: 1488-1497.

Law WJ, Cann KL, Hicks GG. 2006. TLS, EWS and TAF15: a model for transcriptional integration of gene expression. Brief Funct Genomic Proteomic 5: 8-14.

Leichter M, Marko M, Ganou V, Patrinou-Georgoula M, Tora L, Guialis A. 2011. A fraction of the transcription factor TAF15 participates in interactions with a subset of the spliceosomal U1 snRNP complex. Biochim Biophys Acta 1814: 1812-1824.

Li YR, King OD, Shorter J, Gitler AD. 2013. Stress granules as crucibles of ALS pathogenesis. J Cell Biol 201: 361-372.

Lin CL, Bristol LA, Jin L, Dykes-Hoberg M, Crawford T, Clawson L, Rothstein JD. 1998. Aberrant RNA processing in a neurodegenerative disease: the cause for absent EAAT2, a glutamate transporter, in amyotrophic lateral sclerosis. Neuron 20: 589-602.

Lioy DT, Garg SK, Monaghan CE, Raber J, Foust KD, Kaspar BK, Hirrlinger PG, Kirchhoff F, Bissonnette JM, Ballas N, et al. 2011. A role for glia in the progression of Rett's syndrome. $\mathrm{Na}$ ture 475: 497-500.

Mackenzie IR, Neumann M. 2012. FET proteins in frontotemporal dementia and amyotrophic lateral sclerosis. Brain Res 1462: 40-43.

Meissner M, Lopato S, Gotzmann J, Sauermann G, Barta A. 2003. Proto-oncoprotein TLS/FUS is associated to the nuclear matrix and complexed with splicing factors PTB, SRm160, and SR proteins. Exp Cell Res 283: 184-195.

Munoz DG, Neumann M, Kusaka H, Yokota O, Ishihara K, Terada S, Kuroda S, Mackenzie IR. 2009. FUS pathology in baso- philic inclusion body disease. Acta Neuropathol 118: 617-627.

Nakaya T, Alexiou P, Maragkakis M, Chang A, Mourelatos Z. 2013. FUS regulates genes coding for RNA-binding proteins in neurons by binding to their highly conserved introns. RNA 19: 498-509.

Neumann M, Rademakers R, Roeber S, Baker M, Kretzschmar HA, Mackenzie IR. 2009. A new subtype of frontotemporal lobar degeneration with FUS pathology. Brain 132: 2922-2931.

Newnham CM, Hall-Pogar T, Liang S, Wu J, Tian B, Hu J, Lutz CS. 2010. Alternative polyadenylation of MeCP2: Influence of cisacting elements and trans-acting factors. RNA Biol 7: 361-372.

Orlic-Milacic M, Kaufman L, Mikhailov A, Cheung AY, Mah$\operatorname{mood} \mathrm{H}$, Ellis J, Gianakopoulos PJ, Minassian BA, Vincent JB. 2014. Over-expression of either MECP2_e1 or MECP2_e2 in neuronally differentiated cells results in different patterns of gene expression. PLoS One 9: e91742.

Orozco D, Edbauer D. 2013. FUS-mediated alternative splicing in the nervous system: consequences for ALS and FTLD. J Mol Med (Berl) 91: 1343-1354.

Paronetto MP, Minana B, Valcarcel J. 2011. The Ewing sarcoma protein regulates DNA damage-induced alternative splicing. Mol Cell 43: 353-368.

Petri S, Krampfl K, Hashemi F, Schmalbach S, Grothe C, Hori A, Dengler R, Bufler J. 2004. The mRNA expression of AMPA type glutamate receptors in the primary motor cortex of patients with amyotrophic lateral sclerosis: an in situ hybridization study. Neurosci Lett 360: 170-174.

Phatnani HP, Guarnieri P, Friedman BA, Carrasco MA, Muratet M, O'Keeffe S, Nwakeze C, Pauli-Behn F, Newberry KM, Meadows SK, et al. 2013. Intricate interplay between astrocytes and motor neurons in ALS. Proc Natl Acad Sci 110: E756-E765.

Polymenidou M, Lagier-Tourenne C, Hutt KR, Huelga SC, Moran J, Liang TY, Ling SC, Sun E, Wancewicz E, Mazur C, et al. 2011. Long pre-mRNA depletion and RNA missplicing contribute to neuronal vulnerability from loss of TDP-43. Nat Neurosci 14: 459-468.

Polymenidou M, Lagier-Tourenne C, Hutt KR, Bennett CF, Cleveland DW, Yeo GW. 2012. Misregulated RNA processing in amyotrophic lateral sclerosis. Brain Res. 1462: 3-15.

Qiu H, Lee S, Shang Y, Wang WY, Au KF, Kamiya S, Barmada SJ, Finkbeiner S, Lui H, Carlton CE, et al. 2014. ALS-associated mutation FUS-R521C causes DNA damage and RNA splicing defects. J Clin Invest 124: 981-999.

Rabbitts TH, Forster A, Larson R, Nathan P. 1993. Fusion of the dominant negative transcription regulator $\mathrm{CHOP}$ with a novel gene FUS by translocation $\mathrm{t}(12 ; 16)$ in malignant liposarcoma. Nat Genet 4: 175-180.

Rappsilber J, Ryder U, Lamond AI, Mann M. 2002. Large-scale proteomic analysis of the human spliceosome. Genome Res 12: 1231-1245

Renton AE, Chio A, Traynor BJ. 2014. State of play in amyotrophic lateral sclerosis genetics. Nat Neurosci 17: 17-23.

Rogelj B, Easton LE, Bogu GK, Stanton LW, Rot G, Curk T, Zupan B, Sugimoto Y, Modic M, Haberman N, et al. 2012. Widespread binding of FUS along nascent RNA regulates alternative splicing in the brain. Sci Rep 2: 603.

Samaco RC, Nagarajan RP, Braunschweig D, LaSalle JM. 2004. Multiple pathways regulate $\mathrm{MeCP} 2$ expression in normal brain development and exhibit defects in autism-spectrum disorders. Hum Mol Genet 13: 629-639.

Schwartz JC, Ebmeier CC, Podell ER, Heimiller J, Taatjes DI, Cech TR. 2012. FUS binds the CTD of RNA polymerase II 
and regulates its phosphorylation at Ser2. Genes Dev 26: 2690-2695.

Sproviero W, La Bella V, Mazzei R, Valentino P, Rodolico C, Simone IL, Logroscino G, Ungaro C, Magariello A, Patitucci A, et al. 2012. FUS mutations in sporadic amyotrophic lateral sclerosis: clinical and genetic analysis. Neurobiol Aging 33: 837 e831-e835.

Sreedharan J, Blair IP, Tripathi VB, Hu X, Vance C, Rogelj B, Ackerley S, Durnall JC, Williams KL, Buratti E, et al. 2008. TDP-43 mutations in familial and sporadic amyotrophic lateral sclerosis. Science 319: 1668-1672.

Sugino K, Hempel CM, Okaty BW, Arnson HA, Kato S, Dani VS, Nelson SB. 2014. Cell-type-specific repression by methylCpG-binding protein 2 is biased toward long genes. J Neurosci. 34: 12877-12883.

Sun S, Ling SC, Qiu J, Albuquerque CP, Zhou Y, Tokunaga S, Li H, Qiu H, Bui A, Yeo GW, et al. 2015. ALS-causative mutations in FUS/TLS confer gain and loss of function by altered association with SMN and U1-snRNP. Nat Commun 6: 6171.

Takahama K, Oyoshi T. 2013. Specific binding of modified RGG domain in TLS/FUS to G-quadruplex RNA: tyrosines in RGG domain recognize 2'-OH of the riboses of loops in G-quadruplex. J Am Chem Soc 135: 18016-18019.

Takanashi K, Yamaguchi A. 2014. Aggregation of ALS-linked FUS mutant sequesters RNA binding proteins and impairs RNA granules formation. Biochem Biophys Res Commun 452: 600-607.

Tan AY, Manley JL. 2009. The TET family of proteins: functions and roles in disease. J Mol Cell Biol 1: 82-92.

Tan AY, Manley JL. 2010. TLS inhibits RNA polymerase III transcription. Mol Cell Biol 30: 186-196.

Tan AY, Riley TR, Coady T, Bussemaker HJ, Manley JL. 2012. TLS/FUS (translocated in liposarcoma/fused in sarcoma) regulates target gene transcription via single-stranded DNA response elements. Proc Natl Acad Sci 109: 6030-6035.

Udagawa T, Fujioka Y, Tanaka M, Honda D, Yokoi S, Riku Y, Ibi D, Nagai T, Yamada K, Watanabe H, et al. 2015. FUS regulates AMPA receptor function and FTLD/ALS-associated behaviour via GluA1 mRNA stabilization. Nat Commun 6: 7098.

van Blitterswijk M, Landers JE. 2010. RNA processing pathways in amyotrophic lateral sclerosis. Neurogenetics 11: 275-290.

Vance C, Rogelj B, Hortobagyi T, De Vos KJ, Nishimura AL, Sreedharan J, Hu X, Smith B, Ruddy D, Wright P, et al. 2009. Mutations in FUS, an RNA processing protein, cause familial amyotrophic lateral sclerosis type 6. Science 323: 1208-1211.

Vance C, Scotter EL, Nishimura AL, Troakes C, Mitchell JC, Kathe C, Urwin H, Manser C, Miller CC, Hortobagyi T, et al. 2013. ALS mutant FUS disrupts nuclear localization and sequesters wild-type FUS within cytoplasmic stress granules. Hum Mol Genet 22: 2676-2688.

Vanderweyde T, Youmans K, Liu-Yesucevitz L, Wolozin B. 2013. Role of stress granules and RNA-binding proteins in neurodegeneration: a mini-review. Gerontology 59: 524-533.

Virgo L, Samarasinghe S, de Belleroche J. 1996. Analysis of AMPA receptor subunit mRNA expression in control and ALS spinal cord. Neuroreport 7: 2507-2511.

Wang WY, Pan L, Su SC, Quinn EJ, Sasaki M, Jimenez JC, Mackenzie IR, Huang EJ, Tsai LH. 2013. Interaction of FUS and HDAC1 regulates DNA damage response and repair in neurons. Nat Neurosci 16: 1383-1391.

Wu S, Green MR. 1997. Identification of a human protein that recognizes the $3^{\prime}$ splice site during the second step of premRNA splicing. EMBO J 16: 4421-4432.

Yamazaki T, Chen S, Yu Y, Yan B, Haertlein TC, Carrasco MA, Tapia JC, Zhai B, Das R, Lalancette-Hebert M, et al. 2012. FUS-SMN protein interactions link the motor neuron diseases ALS and SMA. Cell Rep 2: 799-806.

Yang L, Embree LJ, Tsai S, Hickstein DD. 1998. Oncoprotein TLS interacts with serine-arginine proteins involved in RNA splicing. J Biol Chem 273: 27761-27764.

Yasuda K, Zhang H, Loiselle D, Haystead T, Macara IG, Mili S. 2013. The RNA-binding protein Fus directs translation of localized mRNAs in APC-RNP granules. I Cell Biol 203: 737-746.

Yasui DH, Xu H, Dunaway KW, Lasalle JM, Jin LW, Maezawa I. 2013. MeCP2 modulates gene expression pathways in astrocytes. Mol Autism 4: 3.

Yasui DH, Gonzales ML, Aflatooni JO, Crary FK, Hu DJ, Gavino BJ, Golub MS, Vincent JB, Carolyn Schanen N, Olson CO, et al. 2014. Mice with an isoform-ablating Mecp2 exon $1 \mathrm{mu}-$ tation recapitulate the neurologic deficits of Rett syndrome. Hum Mol Genet 23: 2447-2458.

Yu Y, Chi B, Xia W, Gangopadhyay J, Yamazaki T, WinkelbauerHurt ME, Yin S, Eliasse Y, Adams E, Shaw CE, et al. 2015. U1 snRNP is mislocalized in ALS patient fibroblasts bearing NLS mutations in FUS and is required for motor neuron outgrowth in zebrafish. Nucleic Acids Res 43: 3208-3218.

Zhang J, Manley JL. 2013. Misregulation of pre-mRNA alternative splicing in cancer. Cancer Discov 3: 1228-1237.

Zhou Z, Licklider LJ, Gygi SP, Reed R. 2002. Comprehensive proteomic analysis of the human spliceosome. Nature 419: 182-185.

Zoghbi HY. 2005. MeCP2 dysfunction in humans and mice. I Child Neurol 20: 736-740. 


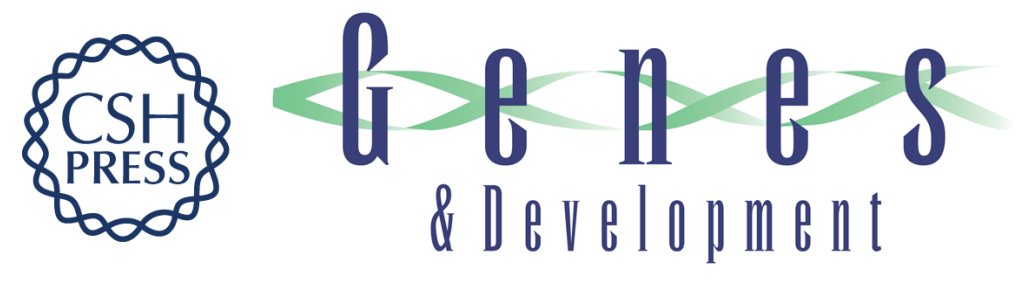

\section{ALS mutations in TLS/FUS disrupt target gene expression}

Tristan H. Coady and James L. Manley

Genes Dev. 2015, 29: originally published online August 6, 2015

Access the most recent version at doi:10.1101/gad.267286.115

\section{Supplemental Material \\ References \\ Creative \\ Commons \\ License}

Email Alerting

Service
http://genesdev.cshlp.org/content/suppl/2015/08/06/gad.267286.115.DC1

This article cites 81 articles, 20 of which can be accessed free at: http://genesdev.cshlp.org/content/29/16/1696.full.html\#ref-list-1

This article is distributed exclusively by Cold Spring Harbor Laboratory Press for the first six months after the full-issue publication date (see

http://genesdev.cshlp.org/site/misc/terms.xhtml). After six months, it is available under a Creative Commons License (Attribution-NonCommercial 4.0 International), as described at http://creativecommons.org/licenses/by-nc/4.0/.

Receive free email alerts when new articles cite this article - sign up in the box at the top right corner of the article or click here.

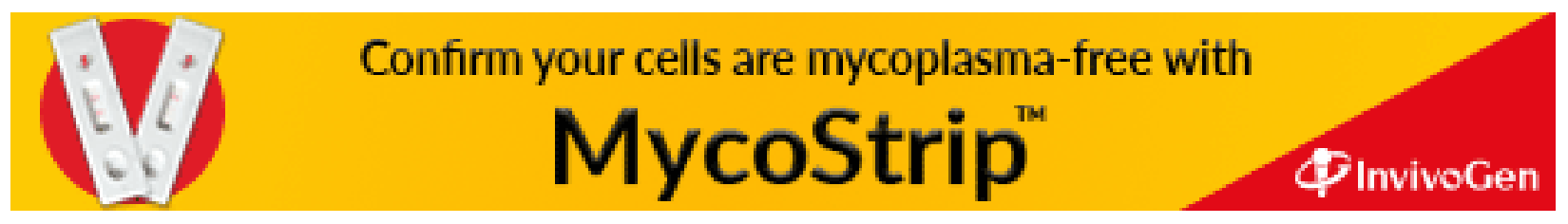

